\title{
Accessibility and Interactive TV: Design Recommendations for the Brazilian Scenario
}

\author{
Lara Schibelsky G. Piccolo ${ }^{1,2}$, Amanda Meincke Melo², \\ and Maria Cecília Calani Baranauskas ${ }^{2}$ \\ ${ }^{1}$ Fundação CPqD - Centro de Pesquisa e Desenvolvimento em Telecomunicações \\ Rod. Campinas Mogi-Mirim, km 118,5, CEP 13086-902, Campinas, SP, Brasil \\ lpiccolo@cpqd.com.br \\ ${ }^{2}$ Instituto de Computação (IC) - Universidade Estadual de Campinas (Unicamp) \\ Caixa Postal 6176, CEP 13083-970, Campinas, SP, Brasil \\ \{amanda, cecília\}@ic.unicamp.br
}

\begin{abstract}
TV can be regarded as the most far-reaching media in Brazil. Its presence is noticed in $90 \%$ of Brazilian homes and it is the main source of information for a major part of the population. The moment of definition and consolidation of the digital TV technology provides us with a unique opportunity for analyzing and discussing this media accessibility. Making sure that TV contents and devices are flexible enough so that people are able to perceive, understand and interact with them is a main asset for its use and an essential requirement for the democratization of information via TV broadcasting. This paper analyzes interactive digital TV accessibility in informal, formal, and technical levels, considering the Brazilian context. In addition, it presents recommendations to design accessible interfaces by referring to the $\mathrm{W} 3 \mathrm{C}$ guidelines 2.0 for Web accessibility and specific recommendations for iDTV.
\end{abstract}

Keywords: Accessibility, Interactive digital TV, User Interfaces for All.

\section{Introduction}

TV can be regarded as the most far-reaching media in Brazil as it is present in $90 \%$ of Brazilian homes, where it plays the role of the major information source for the majority of the population [14]. Making sure that TV contents and devices are flexible enough so that people are able to perceive, understand and interact with them is a main asset for its use and an essential requirement for any process towards the democratization of information via TV broadcasting.

Interactive TV can be defined as an artifact for the dialogue between TV viewers and TV channel producers, a program or service [11]. Therefore it represents a communication media that goes beyond the one-way mass media communication, allowing the TV viewer to change the passive attitude of simply "watching" TV to make choices and have a more direct influence upon the television system.

The digitalization of the TV signal between the broadcasting station and its final users leads to datacasting — the use of a small portion of the signal to broadcast data, 
in addition to the audio-visual content [22]. Therefore, a software layer may enable certain facilities such as interface customization, multiple streams of audio and video, and applications with manifold types of interactivity on a wide range of services. Regarding the user interface, these features may imply, for instance, in a more frequent use of text on-screen, page-browsing systems, the use of menus in association (or not) with remote control buttons, and special user requirements related to new ways of interacting with a device still unknown for many people.

Within this scenario, the accessibility resources provided by the analog TV can no longer be sufficient to assure that a significant number of users are able to fully enjoy this new media. Therefore, the moment of definition and consolidation of this technology, which is currently experienced in the Brazilian context, is a unique opportunity for discussing TV accessibility and implementing solutions which consider the population's needs within its widest extension.

Although directly related to people with disabilities, accessibility does not refer exclusively to this group of users. It is necessary to understand the relation between accessibility and usability, i.e., with the quality in use of computer resources and, consequently, with both digital and social inclusion [3][4][19]. The Digital TV for All report [16] presents a comparative analysis of exclusion in both analog and digital TVs. The report shows that $2.7 \%$ of the population over 16 years presented problems when switching channels on analog TV. This number raises to $7.1 \%$ when considering digital TV. For the population above 75, this number increased from $9 \%$ in the analog TV to $24.7 \%$ in digital TV. The most significant difficulties were found in the use of Electronic Programming Guide (EPG) for switching channels. Users with visual, motor, or cognitive disabilities were the most affected. Exclusion is even worst when the use of interactive services, such as the Digital Teletext, is required.

These and other experiences as well as foreign laws and conventions can subsidize the creation of an accessibility concept for the Brazilian interactive TV. Nevertheless, an analysis which defines the Brazilian context and its particularities is essential. This paper presents an analysis of the interactive digital TV (iDTV), guided by the following questions related to accessibility: How to ensure that an interactive TV application is accessible? As the interactive TV is a convergent media, holding features that have been inherited from both - the current analog TV as well as from the Web environment, is it possible to extend the analog TV accessibility norms with Web accessibility guidelines so that they are applicable to interactive TV? How?

This paper brings into discussion iDTV accessibility in informal, formal, and technical levels, considering the Brazilian context, and presents recommendations to make the interactive digital TV an accessible media. The resulting recommendations draw upon the W3C Web accessibility guidelines and on some specific iDTV recommendations. It is organized as follows: Section 2 situates the accessibility and Universal Design concepts in the Brazilian TV context. Section 3 presents a preliminary analysis of the iDTV subsidies, norms and possibilities. Based on this analysis, Section 4 synthesizes the iDTV accessibility recommendations.

\section{Accessibility, Universal Design and Television}

The term accessibility is commonly associated with the commitment to improve the quality of life to the elderly as well as to people with disability (e.g. perceptual, 
cognitive, motor, multiple impairment), as they generally feel a direct impact from obstacles in different environments, products, and services [2][19][23]. Nevertheless, accessibility considered as the possibility of reaching certain physical spaces, information, products and services, is concerned with quality of life for every human being.

For a more inclusive society, able to acknowledge the differences among people, it is even more important that proposals for the accessibility of people with specific needs be connected to the promotion of the quality of life for everyone [8][19][23][31]. Thus, people with different abilities, whether resulting from aging and disability or not, will benefit from accessible products and services, which do not discriminate them.

Accessibility is directly related to usability and, furthermore, to quality in use of computer systems [3][4][19]. Access and use of Information and Communication Technology (ICT) has received different names within the Human-Computer Interaction field: Universal Accessibility, Universal Usability, Inclusive Design, User Interfaces for All [13][23][30][31]. This approach to design does not imply the development of a unique solution for everyone [31]. It implies the proposal of flexible solutions involving a wide understanding of the role that these systems are supposed to play in the society, the acknowledgment of diversity of contexts and situations in which technology is employed, besides the participation of users in design and evaluation activities [19].

Federal Brazilian laws in effect [2] define accessibility as the possibility for persons with disability to access and use any physical means, communication media, products and services. TV programs are formally considered as accessible as long as they follow the Standard NBR 15290:2005 [2] established by the Brazilian Association of Technical Standards (ABNT). Along with other regulations in effect [5][20], this norm is based on the provisioning of assistive services by TV manufacturers and broadcasters: closed caption, audio description, dubbing and sign language window (in Brazil, the Brazilian Sign Language - LIBRAS).

Although the current regulations demand the provisioning of these services, unofficial discussion lists point out that users, mainly those with disabilities, who count on such resources as the only way to access information on TV, question the amount and quality of information made available.

\section{Interactive Digital TV Accessibility: A Preliminary Analysis}

Organizational Semiotics (OS) [17] has guided our research about iDTV and its artifacts have been used as analytical tool [27]. Through OS, every technical system is within the core of a socio-organizational context and surrounded by the formal and informal layers of the society or the social organization. Thus, the technical systems are under the influence of both formal and informal levels and, at the same time, they have an impact on them. The relations among the informal, formal, and technical levels of the information system are explained through the metaphor known as the "organizational onion". Figure 1 presents one of the OS artifacts, the semiotic onion, which gives an accessibility overview involving the informal, formal, and technical levels of access to information in the Brazilian iDTV. 


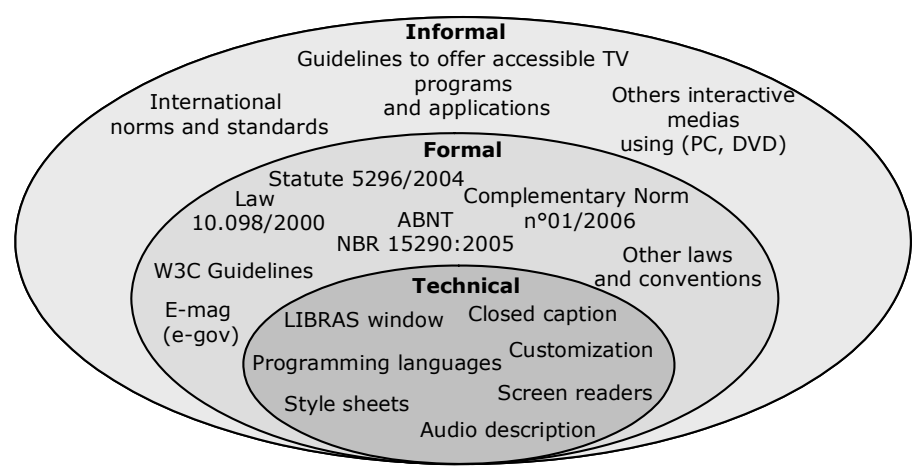

Fig. 1. Interactive Digital TV Accessibility represented by a semiotic onion

\subsection{Informal Level - Subsidies}

This level comprises information which does not formally fall upon the accessibility issue in the Brazilian iDTV, though they are able to support a solution proposal:

- The content production and delivery guidelines and recommendations, as well as the principles of iDTV interface development, which are used around the world.

- Existing international norms and standards, which may be a source of reference for the Brazilian proposal.

- The experience of Brazilian users with other interactive artifacts, such as DVD, computers, cellular phone, and even with the interactivity available on pay TV.

In several European countries, and other nations where the use of digital TV interactivity is consolidated, some ways of dealing with accessibility issues have been established. Nevertheless, formal norms do not exist and there are few recommendations to approach accessibility beyond audio-visual features.

In Portugal, when the digital terrestrial TV was expected to start operations in 2001, an initiative to create guidelines for subsidizing specific accessibility regulations was launched. Among other things, the guidelines suggested that digital TV receivers should be compatible with technology to support citizens with special needs. Such technology included adapted remote control, special keyboard and mouse, screen readers, voice synthesizers, and Braille terminals [7]. As the digital terrestrial TV operation was delayed in the country, this discussion was postponed.

The United Kingdom concentrates the major efforts regarding guidelines for accessible user interface designs on iDTV. The Royal National Institute of Blind (RNIB) defined a set of user interface requirements for digital TV receivers regarding presentation, browsing, and remote control. Although these requirements have been set for persons with visual disabilities, they include universal usability and accessibility principles [29]. RNIB is also one of the organizations responsible for 
Tiresias [33], a font specifically created to increase readability in digital TV text. It has also provided a set of recommendations for iDTV accessible user interface design, including colors, texts, and even tips regarding tests with users [32]. The Consumer Expert Group in the UK has gathered this and other recommendations - including World Web Consortium (W3C) guidelines - in a report aimed at helping the government to ensure that the digital TV equipment is also appropriate for the elderly and physically impaired people [9].

The similarity between the currently available actions related to interactive TV and Internet services (e.g.: browsing and data input) as well as the convergence between the two media [28] can lead to the appropriation of Web accessibility knowledge that has already been acquired, even though adjustments may be necessary. Since 1999, the W3C Web Content Accessibility Guidelines 1.0 [34] has been a reference for the development of accessible websites. Currently, the 2.0 version of the guidelines has a multimedia approach involving new technologies, which surpass the scope of the Web [35]. In addition to the recommendations concerned with content accessibility, a few others have been defined for the user agents (e.g., Web browsers and assistive technologies), which also comprise the TV receivers that, among other things, are responsible for content presentation and browsing. The new set of guidelines was grouped under four principles considered essential to access and use of the Web by anyone: the content must be perceivable; interface components in the content must be operable; content and controls must be understandable; content must be robust enough to work with current and future user agents, including assistive technologies.

\subsection{Formal Level - Norms}

The Brazilian current regulations concern the formal level of information on iDTV. The use of accessibility resources and technical artifacts on analog TV broadcasting is regulated by a hierarchical set of laws and norms as represented by Figure 2 .

Law 10.098, December 192000 - It establishes, among other issues, general guidelines and basic criteria to promote media accessibility to persons with disability or mobility impairment. The law focuses on TV broadcasting services accessibility for persons with hearing disabilities [6].

Decree-law 5.2962 December 2004 - It covers the use of closed captioning, LIBRAS (Brazilian Sign Language) window and audio description features in analog TV programming and enforces the use of these artifacts on digital TV as well. It establishes the creation of supplementary standards to regulate the use of these artifacts [5].

Supplementary Standard 01/2006 - Accessibility in image and sound broadcasting and TV re-broadcasting for persons with disabilities. The law was enacted on June 28,2006 , after 64 days of public consultation. It defines accessibility resources, terms, goals and non-compliance penalties. It refers to ABNT Standard described below [20].

ABNT NBR 15290:2005 Technical Standard - Accessibility in TV Broadcasting. It establishes guidelines for the production and delivery of analogical and digital TV to persons with disabilities, including closed captioning, audio descriptions and LIBRAS window. Effective from November 30, 2005 [2].

Fig. 2. Brazilian current regulations on TV accessibility 
Regulations [5][20] govern the transition from analog to digital terrestrial broadcasting, except for cable and satellite TV services, which in some cases are already digital and interactive in Brazil. For this reason, an initiative [21] has been launched to request changes to Decree-law 5.296/04 so that the guidelines can be extended to payable TV.

TV interactivity is mentioned in Supplementary Standard 01/2006 [20]: “allowing the addition of sentences in Portuguese, so that persons with visual and intellectual disabilities can select the desired menu options and interactive features in an independent way". We understand that those interactive features are related to the applications transmitted or embedded in the receiver. In addition, new technical possibilities are taken into consideration in this Standard "to allow the optional use of the LIBRAS window in all TV programming".

The year 2017 is the deadline for making the daily programming fully accessible, when it is expected that digital TV will be present in the majority of homes in Brazil. ABNT NBR 15290:2005 Technical Standard [2] provides guidelines for producing and delivering accessible content that apply to all TV broadcasters and producers, including cable, satellite, IP and digital broadcasting TV. An analysis of this regulation indicates that the digital technology potential has not been fully explored in regard to accessibility and some possibilities have not been taken into consideration, such as using multiple audio streams for a single video; sharing the broadcast channel to deliver simultaneously different audio-visual content; using different closed captioning presentations, among others. As occurs with international standards, aspects related to the design of interactive applications interfaces are not addressed in the Brazilian standard, such as options to allow changing color, font type, text size and positioning.

Focusing on the production and delivery of assistive services, both Brazilian and international laws and standards are addressed to persons with disabilities. However, the iDTV accessibility concept should go further, benefiting much more people.

\subsection{Technical Level - Possibilities}

Accessible iDTV applications depend on receiver features. In addition, existing analog TV customization solutions and services can be extended to iDTV.

W3C guidelines for Web accessibility are based on consolidated and standardized technologies, such as HyperText Markup Language (HTML) and Cascade Style Sheet (CSS), helping developers adequately encode and separate a page structure from its presentation [18]. To accomplish accessible iDTV applications, the receiver has to be prepared for it: both hardware and software must comply with specific standards and assistive technologies. If declarative language is supported - a markup language (HTML, for example), that uses a presentation engine - an interactive application implementation can be similar to the development of a Web page, making it easier to comply with $\mathrm{W} 3 \mathrm{C}$ recommendations and helping developers to work at a higher level of abstraction. However, if the receiver contains an execution engine (procedural middleware), using JAVA language for example, the implementation of accessible applications is also possible, but developers will need to take extra care and implement for each new application some accessibility resources already included in the presentation engine. In this case, it is important to standarize a set of Application 
Programming Interfaces (APIs) for the procedural middleware, optimizing the developers work and enabling the interoperability among multiple receiver models or among different TV platforms [10].

Digital TV opens up a whole range of new possibilities in terms of implementation and improvement of existing analog TV assistive services offered:

- Closed caption: Digital TV enables new functions to subtitling such as the option to change font style, color and size, the use of transparence or change the color of the subtitle background, the use of icons or small graphics in the text [10].

- Audio description: Multiple audio streams can be used for a single video, making it possible the combination of audio description and original sound or dubbing. Some receivers can send audio description to a headphone and the original sound to the conventional TV audio output. Taking into account the multimedia nature of iDTV, the audio description concept could be extended, so that non-textual output could be produced for the remaining textual or graphic elements through the use of assistive techonologies.

- LIBRAS window: In analog TV transmission, the LIBRAS window occupies part of the screen. In many cases, however, the window is not large enough to allow the user to read all body language signs and cues required by the sign language. It is necessary to investigate ways of implementing optional LIBRAS window and to realize a feasibility analysis of automation of sign language generation with human figures and avatars.

TV personalization - the method that captures the user's profiles, in order to use them to search or to show a specific data [1][15] - could be used to meet the needs of different users or user groups or receivers, for example, storing preferences as text size, color combination, warnings, etc in a Smart Card [12]. Although it is a trend around the world, implementing TV personalization would generate extra costs on the receiver. For this reason and considering the user experiences in this moment of transition, it is still important to consider TV as a collective medium to propose an accessibility solution to Brazil.

\section{Recommendations for Accessible Services Through iDTV}

An accessible iDTV solution should not be limited to assistive services. It should be taken into consideration the TV content, the artifacts used for the interaction with the user, such as a receiver and a remote control, and last, but not least, the user's expectations and experiences related to the use of interactive artifacts. Based on this fact and considering the Universal Design proposal - to promote the design of widely usable and accessible products and environments and the development of solutions that support assistive technologies - this section offers a summary of the main factors to be considered in the iDTV context and suggests recommendations for the interaction design, which involve both technical and social factors resulting from the previous analysis. 


\subsection{The Triad: User, Remote Control and Receiver}

Surveys conducted with visually impaired persons in the United Kingdom showed which particular functions they would like to have implemented on TV: the option to change text size and combination of colors; the possibility of adding extra time to review information and removing available functions, to name a few [12]. In order to propose the development of services and artifacts suitable for all users, it is essential to know and identify the needs of the population as a whole, including persons with disabilities. Interviews, ethnographic methods, usability evaluation, semiotic analysis and even inclusive design methodologies [19] can be applied.

In Brazil, where a large section of the population has a low level of education and digital literacy and has never had access to interactive services on TV, it is absolutely necessary to find ways to identify the user experience with other artifacts, to understand how this experience can be reflected in the use of iDTV and also to know the population's expectations in regard to this media.

Although the remote control is the main device to interact with iDTV, many users restrict its use to the channel search by going up and down and by using the number buttons [11]. The high level of complexity and inconsistency in user interfaces are some of the common problems of remote control [24]. Some researchers point out the importance of establishing a standard or a convention for the use of the remote control buttons so that the user could associate the functionality with the button position [9][12][16].

To achieve an accessible iDTV, the content should be delivered to the user under the Universal Design perspective and the receiver should be prepared to use the technical artifacts. Although Brazil has chosen the ISDB Japanese standard for terrestrial transmission, the receiver middleware has not been defined yet. Whatever technical and market solution is adopted, it is essential to consider and establish standard accessibility requirements. Nevertheless, support to assistive technologies, personalization and other functions can incur additional manufacturing costs on the receivers.

\subsection{Recommendations for iDTV Interface Design}

Brazil, as well as other countries, presents gaps on formal, informal and technical levels in establishing criteria to design accessible iDTV interfaces and to provide receiver compatibility with assistive technologies.

Recommendations for iDTV interface design presented in Table 1 take as reference W3C Web Content Accessibility Guidelines 2.0 [35], as well as other specific iDTV accessibility recommendations [29][32][9], including comments regarding the Brazilian context. Besides highlighting the need to be compatible with assistive technologies, W3C guidelines also include part of iDTV recommendations, excepted by some iDTV specificities.

Table 1 was organized under the four principles defined by $\mathrm{W} 3 \mathrm{C}$ guidelines. Specific recommendations for iDTV are primarily based on RNIB [29] followed by Tiresias [32] and The Consumer Expert Group [9]. Frequently, there are similarities between references, because they use the same research basis. Each iDTV specific recommendation was classified according to W3C 2.0 Guidelines or considered as 
being supplementary. Some comments are presented as a contextualized analysis of both guidelines and its relation to the Brazilian formal level on iDTV and Nielsen's Heuristics [25]. From the Ten Usability Heuristics, seven were identified showing the association between accessibility and usability. Results of the analysis and assistive services found in the Brazilian norms are summarized in the Analysis column.

Although remote control is a key-element for TV interactivity design, such device was not included due to limitation and scope of this paper. The resulting recommendations do not intend to be exhaustive regarding usability and accessibility issues; they intend to support design decisions.

Table 1. Recommendations to provide an acessible iDTV

\begin{tabular}{|c|c|c|}
\hline References Guidelines & \begin{tabular}{|l} 
Analysis \\
\end{tabular} & Recommendations \\
\hline \multicolumn{3}{|c|}{ Principle $1 \mathrm{~W} 3 \mathrm{C}$ : Content must be perceivable } \\
\hline $\begin{array}{l}\text { 1.1) Provide text alternatives } \\
\text { for all non-text content [35]. } \\
\text { 1.11) Avoid icons, or offer a } \\
\text { text alternative[29]. }\end{array}$ & $\begin{array}{l}\text { Text alternatives are used by } \\
\text { assistive technologies such as } \\
\text { screen readers or Braille } \\
\text { printers. }\end{array}$ & $\begin{array}{l}\text { 1. Provide text alternatives for all } \\
\text { non-text content (icons, stable } \\
\text { images, animations). }\end{array}$ \\
\hline $\begin{array}{l}\text { 1.2) Provide synchronized } \\
\text { alternatives for multimedia } \\
\text { [35] (captions, audio } \\
\text { descriptions and extended - } \\
\text { added by pausing the video, } \\
\text { full multimedia text } \\
\text { alternative including any } \\
\text { interaction). } \\
\text { 5.3) Keep feature settings } \\
\text { between services [29]. }\end{array}$ & $\begin{array}{l}\text { ABNT Standard [2] provides } \\
\text { guidelines for generating } \\
\text { closed captions, audio } \\
\text { description and LIBRAS } \\
\text { window, as per [20] } \\
\text { requirements. Full multimedia } \\
\text { text alternative is included in } \\
\text { previous recommendation. }\end{array}$ & $\begin{array}{l}\text { 2. Do not change any assistive } \\
\text { service settings while switching } \\
\text { channels (or moving from one } \\
\text { application to another). }\end{array}$ \\
\hline \multirow{2}{*}{$\begin{array}{l}\text { 1.3) Ensure that information } \\
\text { and structure can be } \\
\text { separated from presentation } \\
\text { [35]. } \\
\text { 1.3.2) Any information that is } \\
\text { conveyed by color is also } \\
\text { visually evident without colour. } \\
\text { 1.2) Provide user option to } \\
\text { change the size of displayed } \\
\text { text [29]. } \\
\text { 1.5) Never solely on colour } \\
\text { to convey information [29]. }\end{array}$} & \multirow{2}{*}{$\begin{array}{l}\text { Ensure compatibility among } \\
\text { user agents (receivers), } \\
\text { enabling different content } \\
\text { presentations and information } \\
\text { integrity. Font size should be } \\
\text { also a presentation attribute, } \\
\text { although W3C does not } \\
\text { clearly state it. }\end{array}$} & $\begin{array}{l}\text { 3. The conveyed information } \\
\text { must be clear, regardless of } \\
\text { screen size, format, disposition } \\
\text { and orientation. }\end{array}$ \\
\hline & & $\begin{array}{l}\text { 4. Provide user option to change } \\
\text { the size of displayed text. }\end{array}$ \\
\hline \multirow{2}{*}{$\begin{array}{l}\text { 1.4) Make it easy to } \\
\text { distinguish foreground } \\
\text { information from its } \\
\text { background [35]. }\end{array}$} & \multirow{4}{*}{$\begin{array}{l}\text { The user agent may change } \\
\text { color and contrast, relating } \\
\text { Recommendations } 5 \text { with } 3 \\
\text { and } 4 . \\
\text { Serif fonts are illegible on } \\
\text { TV. }\end{array}$} & $\begin{array}{l}\text { 5. Provide user option to change } \\
\text { contrast or text colours. }\end{array}$ \\
\hline & & $\begin{array}{l}\text { 6. Avoid text over textured } \\
\text { background. }\end{array}$ \\
\hline $\begin{array}{l}\text { 1.1) Provide user option to } \\
\text { change the display to high } \\
\text { contrast and inverted text }\end{array}$ & & $\begin{array}{l}\text { 7. Avoid color inversion when } \\
\text { highlighting an interface element } \\
\text { (e.g., when focus is applied). }\end{array}$ \\
\hline 1.4) Avoid text over textured & & $\begin{array}{l}\text { 8. Use TV-suitable fonts. Tiresias } \\
\text { is recommended. }\end{array}$ \\
\hline
\end{tabular}


Table 1. (continued)

\begin{tabular}{|c|c|c|}
\hline References Guidelines & Analysis & Recommendations \\
\hline $\begin{array}{l}\text { background [29]. } \\
\text { 1.9) To highlight an option, } \\
\text { favour markers over } \\
\text { inversion [29]. } \\
\text { 1.3) Use a clear font [29]. } \\
\text { Text size should be a } \\
\text { minimum of } 24 \text { points [32]. }\end{array}$ & & $\begin{array}{l}\text { 9. Text size should be a } \\
\text { minimum of } 24 \text { pts. }\end{array}$ \\
\hline $\begin{array}{l}\text { 1.8) Apply readability } \\
\text { guidelines [29]. }\end{array}$ & $\begin{array}{l}\text { For RNIB, readability is } \\
\text { related to the presentation } \\
\text { itself, whereas for W3C it } \\
\text { refers to text intelligibility. } \\
\text { ABNT defines presentation } \\
\text { guidelines for closed captions } \\
\text { design. }\end{array}$ & $\begin{array}{l}\text { 10. Favour lower case text over } \\
\text { upper case (mixed is ideal); avoid } \\
\text { italic, obliqúe and condensed } \\
\text { text; favour left-align; follow } \\
\text { ISO7001 arrows specification; } \\
\text { ensure words have a clear space } \\
\text { around them; use Arabic } \\
\text { numerals rather than Roman. }\end{array}$ \\
\hline Use of Colors on TV [32]. & $\begin{array}{l}\text { Screen color may strongly } \\
\text { vary from computer to TV. } \\
\text { The application designer must } \\
\text { perform this check. Avoid } \\
\text { visual tracking. }\end{array}$ & $\begin{array}{l}\text { 11. Avoid combinations of red } \\
\text { and green; avoid pure red or } \\
\text { white colours; use colours with a } \\
\text { maximum of } 85 \% \text { saturation; } \\
\text { provide generous inter-line } \\
\text { spacing. }\end{array}$ \\
\hline \multicolumn{3}{|c|}{ Principle 2: Interface components in the content must be operable. } \\
\hline $\begin{array}{l}\text { 2.1) Make all functionality } \\
\text { operable via a keyboard } \\
\text { interface [35]. }\end{array}$ & $\begin{array}{l}\text { Remote control is the } \\
\text { interaction device. Interacting } \\
\text { with downloaded applications } \\
\text { must be possible through any } \\
\text { remote control. }\end{array}$ & $\begin{array}{l}\text { 12. Allow interaction through } \\
\text { remote control main buttons. }\end{array}$ \\
\hline $\begin{array}{l}\text { 2.2) Allow users to control } \\
\text { time limits on their reading or } \\
\text { interaction [35]. }\end{array}$ & $\begin{array}{l}\text { Users facing interaction } \\
\text { problems may find no access } \\
\text { to specific features due to } \\
\text { timeout. }\end{array}$ & $\begin{array}{l}\text { 13. User may disable or extend } \\
\text { an interaction timeout. }\end{array}$ \\
\hline $\begin{array}{l}\text { 2.3) Allow users to avoid } \\
\text { content that could cause } \\
\text { seizures due to } \\
\text { photosensitivity [35]. } \\
\text { 1.7) Avoid flashing [29]. } \\
\text { 1.10) Avoid, or provide an } \\
\text { option to disable, brief } \\
\text { display messages [29]. }\end{array}$ & $\begin{array}{l}\text { W3C refers to size, frequency } \\
\text { and brightness boundaries for } \\
\text { dynamic images usage. Such } \\
\text { boundaries must be evaluated } \\
\text { for iDTV. }\end{array}$ & 14. Avoid flashing objects. \\
\hline \multirow{3}{*}{$\begin{array}{l}\text { 2.4) Provide mechanisms to } \\
\text { help users find content, orient } \\
\text { themselves within it, and } \\
\text { navigate through it [35]. } \\
\text { 2.1) Provide numerical } \\
\text { navigation to all functions } \\
\text { and links [29]. } \\
\text { 2.2) Provide the option of } \\
\text { audible feedback of } \\
\text { navigation [29]. }\end{array}$} & \multirow{3}{*}{$\begin{array}{l}\text { RNIB } 2.1,2.2 \text { and } 2.3 \\
\text { recommendations are mainly } \\
\text { aimed at visually impaired } \\
\text { persons. } \\
\text { A standard interaction model } \\
\text { prevents the user to undergo a } \\
\text { learning process each time a } \\
\text { new application is launched } \\
{[12] .}\end{array}$} & $\begin{array}{l}\text { 15. Provide numerical navigation } \\
\text { to all functions and links. }\end{array}$ \\
\hline & & $\begin{array}{l}\text { 16. Provide the option of audible } \\
\text { feedback of navigation. }\end{array}$ \\
\hline & & $\begin{array}{l}\text { 17. Provide spoken feedback on } \\
\text { navigation (optional). }\end{array}$ \\
\hline
\end{tabular}


Table 1. (continued)

\begin{tabular}{|c|c|c|}
\hline References Guidelines & Analysis & Recommendations \\
\hline \multicolumn{3}{|l|}{$\begin{array}{l}\text { 2.3) Provide spoken feedback } \\
\text { [29]. }\end{array}$} \\
\hline \multirow{4}{*}{$\begin{array}{l}\text { 2.5) Help users avoid } \\
\text { mistakes and make it easy to } \\
\text { correct mistakes that do } \\
\text { occur [35]. }\end{array}$} & \multirow{4}{*}{$\begin{array}{l}\text { Related to Nielsen's } \\
\text { heuristics: } 3 \text { - User control } \\
\text { and freedom; } 5 \text { - Error } \\
\text { prevention; } 9 \text { - Help users } \\
\text { recognize, diagnose, and } \\
\text { recover from errors [25]. }\end{array}$} & $\begin{array}{l}\text { 18. Provide an exit option for } \\
\text { each application feature. }\end{array}$ \\
\hline & & 19. Support undo and redo. \\
\hline & & $\begin{array}{l}\text { 20. Prompt user before running } \\
\text { an operation. }\end{array}$ \\
\hline & & $\begin{array}{l}\text { 21. Present clear error messages } \\
\text { and troubleshooting. }\end{array}$ \\
\hline $\begin{array}{l}\text { 1.6) Ensure that 'please wait' } \\
\text { messages are obvious [29]. }\end{array}$ & $\begin{array}{l}\text { Heuristic } 1[25] \text { : Visibility of } \\
\text { system status. }\end{array}$ & $\begin{array}{l}\text { 22. Display status messages } \\
\text { while system is running. }\end{array}$ \\
\hline \multicolumn{3}{|c|}{ Principle 3: Content and controls must be understandable } \\
\hline $\begin{array}{l}\text { 3.1) Make text content } \\
\text { readable and understandable } \\
\text { 3.1.5) When text requires } \\
\text { reading ability more advanced } \\
\text { than the lower secondary } \\
\text { education level, supplemental } \\
\text { content is available that does not } \\
\text { require reading ability more } \\
\text { advanced than the lower } \\
\text { secondary education leve. [35]. }\end{array}$ & $\begin{array}{l}\text { Unlike W3C 3.1.5 } \\
\text { recommendation, all the text } \\
\text { must be intelligible to target } \\
\text { audience, so it should not } \\
\text { require additional } \\
\text { information. Heuristic } 2 \text { - } \\
\text { considers the user language: } \\
\text { Match between system and } \\
\text { the real world [25]. }\end{array}$ & $\begin{array}{l}\text { 23. All texts in the application } \\
\text { must be target audience-oriented, } \\
\text { i.e., an application designed for a } \\
\text { low-literacy audience must } \\
\text { present texts accordingly. }\end{array}$ \\
\hline \multirow{2}{*}{$\begin{array}{l}\text { 3.2) Make the placement and } \\
\text { functionality of content } \\
\text { predictable. } \\
\text { 3.2.4) Components that have the } \\
\text { same functionality are identified } \\
\text { consistently[35]. } \\
\text { 1.7) Avoid scrolling text[29]. }\end{array}$} & \multirow{2}{*}{$\begin{array}{l}\text { Scrolling text bar is an } \\
\text { unknown TV artifact. Most } \\
\text { users may find it difficult to } \\
\text { encounter a specific interface } \\
\text { component. }\end{array}$} & $\begin{array}{l}\text { 24. Place interface components to } \\
\text { help users move through } \\
\text { predictable paths. }\end{array}$ \\
\hline & & 25. Avoid scrolling text. \\
\hline \multirow[t]{2}{*}{ 5.1) Ensure consistency [29]. } & \multirow{2}{*}{$\begin{array}{l}\text { All interactive artifacts must } \\
\text { be consistent, enabling the } \\
\text { user to associate the browsing } \\
\text { mechanism with the remote } \\
\text { control. } \\
\text { Multifunctional buttons: } \\
\text { consistency and } \\
\text { standardization when } \\
\text { associating functions with the } \\
\text { remote control buttons. } \\
\text { Heuristics } 4 \text { - Consistency } \\
\text { and standards [25]. }\end{array}$} & $\begin{array}{l}\text { 26. All symbols and text should } \\
\text { be consistent on the remote } \\
\text { control, on-screen information, } \\
\text { user manual and speech output. }\end{array}$ \\
\hline & & $\begin{array}{l}\text { 27. If case of using } \\
\text { multifunctional buttons, be } \\
\text { consistent when associating } \\
\text { functions. }\end{array}$ \\
\hline $\begin{array}{l}\text { Offer the user possibilities to } \\
\text { tailor functionality and } \\
\text { interface [16]. }\end{array}$ & $\begin{array}{l}\text { The same as Heuristics } 8 \text { - } \\
\text { Flexibility and efficiency of } \\
\text { use [25]. }\end{array}$ & $\begin{array}{l}\text { 28. Offer the user the possibility } \\
\text { to tailor functionality and } \\
\text { interface. }\end{array}$ \\
\hline \multicolumn{3}{|c|}{$\begin{array}{l}\text { Principle 4: Content should be robust enough to work with current and future user agents } \\
\text { (including assistive technologies) }\end{array}$} \\
\hline $\begin{array}{l}\text { 4.1) Support compatibility } \\
\text { with current and future user } \\
\text { agents (including assistive }\end{array}$ & $\begin{array}{l}\text { Compatibility with assistives } \\
\text { techonologies. According to } \\
\text { [20], the announcement in }\end{array}$ & $\begin{array}{l}\text { 29. Ensure that user agents can } \\
\text { accurately interpret parsable } \\
\text { content, using standard controls }\end{array}$ \\
\hline
\end{tabular}


Table 1. (continued)

\begin{tabular}{|c|c|c|}
\hline References Guidelines & Analysis & Recommendations \\
\hline \multirow[t]{2}{*}{ technologies) [35]. } & \multirow[b]{2}{*}{$\begin{array}{l}\text { Portuguese of menus and } \\
\text { other interactive features is } \\
\text { required. The announcement } \\
\text { might be played by assistive } \\
\text { technologies. }\end{array}$} & from accessible technologies. \\
\hline & & $\begin{array}{l}\text { 30. Make menus and other } \\
\text { interactive text features } \\
\text { compatible with assistive } \\
\text { technologies. }\end{array}$ \\
\hline $\begin{array}{l}\text { 4.2) Ensure that content is } \\
\text { accessible or provide an } \\
\text { accessible alternative. }\end{array}$ & $\begin{array}{l}\text { Compliance with other } \\
\text { guidelines. W3C describes } 3 \\
\text { implementation success } \\
\text { levels. All content must have } \\
\text { at least level } 1 \text { implemented. } \\
\text { A set of minimum } \\
\text { requirements must be defined } \\
\text { to iDTV. }\end{array}$ & 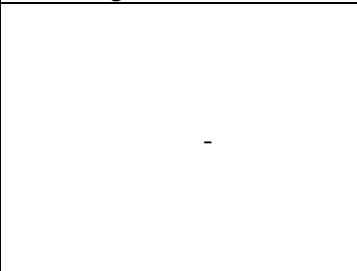 \\
\hline
\end{tabular}

This wider set of recommendations is beyond design issues. Most part of recommendations should be understood as receiver requirements for the iDTV Brazilian solution, in order to support accessible contents and applications execution. Moreover, according to $\mathrm{W} 3 \mathrm{C}$ presentation and content separation practice, such recommendations can also optimize compatibility of iDTV contents with other devices, such as mobile terminals and the Web.

\section{Conclusions}

Unlike analog TV, an accessible iDTV solution should not be restricted to assistive services. It should consider the TV content, the artifacts used for the interaction, such as a receiver and a remote control and the user's expectations and experiences related to the use of interactive artifacts.

Technically, the content should be delivered to the user under the Universal Design perspective and the receiver should be prepared to use the artifacts. At present, when iDTV technology is being defined in Brazil, there is a unique opportunity for the accessibility of this media to be discussed and implemented according to the population's needs within its widest extension.

This paper presented and discussed the results obtained from an iDTV analysis regarding the iDTV informal level subsidies, the formal level presented according to the norms in effect, and the level of possibilities derived from technical issues. Moreover, based upon the $\mathrm{W} 3 \mathrm{C}$ guidelines and the specific recommendations for iDTV, it has synthesized a set of recommendations for iDTV accessibility within the Brazilian scenario.

In continuity of this work, we intend to validate the set of recommendations in iDTV applications for e-Gov, within an inclusive design scenario. As design standards start to be considered, inclusive practices would be helpful in verifying the recommendations more effectively - before their consolidation takes place.

Acknowledgments. The authors thank FUNTTEL and CNPq (476381/2004-5) for funding. 


\section{References}

1. Ardissono, L., Kobsa, A., Maybury, M.: Personalized Digital Television. In: Targeting programs to individual users, p. 331. Kluwer Academic Publishers, Boston, MA (2004)

2. Associação Brasileira de Normas Técnicas - ABNT: NBR 15290: Acessibilidade em Comunicação na Televisão, IV. Rio de Janeiro (2005), http://www.mj.gov.br/sedh/ct/ corde/dpdh/corde/ABNT/NBR15290.pdf

3. Bergman, E., Johnson, E.: Towards Accessible Human-Computer Interaction. In: Nielsen, J. (ed.) Advances in Human-Computer Interaction, Ablex Publishing, Norwood (1995)

4. Bevan, N.: Quality in Use for All. In: Stephanidis, C. (ed.) User Interfaces for All: Concepts, Methods, and Tools, Lawrence Erlbaum, Mahwah (2001)

5. Brasil: Decreto Lei No 5.296, de 02 de Dezembro de 2004 (2004), https://www.planalto.gov.br/ccivil/_ato2004-2006/2004/decreto/d5296.htm

6. Brasil: Lei No 10.098, de 19 de Dezembro de 2000 (2000) (Accessed 30 September 2006), https://www.planalto.gov.br/ccivil/leis/110098.htm

7. Centro de Engenharia de Reabilitação em Tecnologias de Informação e Comunicação CERTIC: GUIA Lança Proposta para Necessidades Especiais (2001) (Accessed 17 December 2006), http://www.acessibilidade.net/historia/putma.php

8. Connell, B.R., Jones, M., Mace, R., et al.: About UD: Universal Design Principles. Version 2.0. Raleigh: The Center for Universal Design (1997), http://www.design.ncsu.edu/ cud/about_ud/udprinciples.htm

9. Consumer Expert Group: Digital TV Equipment: Vulnerable Consumer Requirements 8-10 (2006), http://www.digitaltelevision.gov.uk/pdf_documents/publications/ digtv_equipment-march06.pdf

10. European Committee for Electrotechnical Standardization - CENELEC: Standardisation Requirements for Access to Digital TV and Interactive Services by Disabled People (2003), http://www.cenelec.org/NR/rdonlyres/C4C6543B-8134-472D-BF06-009AEBA6A5B1/0/ interimreportTVforAll.pdf

11. Gawlinski, M.: Interactive Television Production, p. 288. Focal Press, Oxford (2003)

12. Gill, J.M., Perera, S.A.: Accessible Universal Design of Interactive Digital Television. In: 1st European Interactive Television Conference, Brighton, pp. 83-89 (2003)

13. Hull, L.: Accessibility: It's not just for disabilities any more. Interactions 11(2), 36-41 (2004)

14. Instituto Brasileiro de Geografia e Estatística: Pesquisa Nacional por Amostra de Domicílios - Síntese de Indicadores. Tables 7.1.1b and 7.2 (2003), http://www.ibge.gov.br/ home/estatistica/populacao/trabalhoerendimento/pnad2003/

15. Kastidou, K.G., Cohen, R.: An Approach for delivering personalizes ads in interactive TV customized to both users and advertisers. In: Proceedings of the Fourth European Conference on Interactive Television, Athens, pp. 121-129 (2006)

16. Klein, A.J., et al.: Digital Television for All - A Report on Usability and Accessible Design (2003), http://www.digitaltelevision.gov.uk/publications/pub_dtv_for_all.html

17. Liu, K.: Semiotics in Information Systems Engineering. Cambridge University Press, Cambridge (2000)

18. Melo, A.M., Baranauskas, M.C.C.: Design e Avaliação de Tecnologia Acessível. In: Barcellos, M.P., Loureiro, A.A (eds.) A Universalidade da Computação: um Agente de Inovação e Desenvolvimento. XXIV Jornadas de Atualização em Informática, pp. 1500 1544. SBC, Porto Alegre (2005) 
19. Melo, A.M., Baranauskas, M.C.C.: Design Inclusivo de Sistemas de Informação na Web. In: Teixeira, C.A.C., et al. (eds.) Tópicos em Sistemas Interativos e Colaborativos. VII Simpósio Sobre Fatores Humanos em Sistemas Computacionais, pp. 167-212. SBC, Natal (2006)

20. Ministério das Comunicações: Norma Complementar No 01/2006. Diário Oficial da União No 122, quarta-feira, 28 de junho de 2006. Acessibilidade da Pessoa com Deficiência á Programação de Rádio e TV (2006), http://www2.portoalegre.rs.gov.br/seacis/ default.php?reg=16\&p_secao=24

21. Ministério Público Federal: Ata do Grupo de Trabalho Inclusão de Pessoas com Deficiência. Reunião com Agência Nacional de Telecomunicações, Ministério das Comunicações e Coordenadoria Nacional para a Integração da Pessoa Portadora de Deficiência (2006), http://pfdc.pgr.mpf.gov.br/grupos-de-trabalho/folder.2006-0130.7327540164/ata-reuniao-anatel-e-ministerio-das-comunicacoes.pdf

22. Montez, C., Becker, V: TV Digital Interativa: Conceitos, Desafios e Perspectivas para o Brasil, 2ed. Ed. da UFSC, Florianópolis, p. 200 (2005)

23. Nicolle, C., Abascal, J. (eds.): Inclusive Design Guidelines for HCI, p. 285. Taylor \& Francis, Abington (2001)

24. Nielsen, Jakob: Remote Control Anarchy (2004), http://www.useit.com/alertbox/20040607.html

25. Nielsen, Jakob: Ten Usability Heuristics (2005), http://www.useit.com/papers/heuristic/heuristic_list.html

26. Office of Communication - OFCON: Guidelines on the Provision of Television Access Services (2006), http://www.ofcom.org.uk/tv/ifi/guidance/tv_access_serv/guidelines/

27. Piccolo, L.S.G., Baranauskas, M.C.C.: Desafios de Design para TV Digital Interativa. In: Teixeira, C.A.C, et al. (eds.) Tópicos em Sistemas Interativos e Colaborativos. VII Simpósio Sobre Fatores Humanos em Sistemas Computacionais, pp. 1-10. SBC, Natal (2006)

28. Roibás, A.C., Sala, R.: Main HCI Issues for the Design of Interfaces for Ubiquitous Interactive Multimedia Broadcast. In: Interactions Magazine, March-April, pp. 51-53. ACM Press, New York (2004)

29. Royal National Institute of Blind - RNIB: Guidelines for designers of digital TV user interfaces (2005), http://www.rnib.org.uk/xpedio/groups/public/documents/publicwebsite/ public_userinterfaces.doc

30. Shneiderman, B.: Universal Usability. Communications of the ACM 43(5), 85-91 (2000)

31. Stephanidis, C.: User Interfaces for All: New Perspectives into Human-Computer Interactions. In: Stephanidis, C. (ed.) User Interfaces for All: Concepts, Methods, and Tools, pp. 3-17. Lawrence Erlbaum, New Jersey (2001)

32. Tiresias: Guidelines. Television (2007), http://www.tiresias.org/guidelines/television.htm

33. Tiresias: Tiresias Screenfont - Television Subtitling (2000), http://www.tiresias.org/ fonts/screenfont.htm

34. W3C: Web Content Accessibility Guidelines 1.0 (1999), http://www.w3.org/TR/WAIWEBCONTENT/

35. W3C: Web Content Accessibility Guidelines 2.0 (2006), http://www.w3.org/TR/WCAG20/

36. Zimmerman, J., et al.: Interface Design for MyInfo: a Personal News Demonstrator Combining Web and TV Content. In: INTERACT'2003, pp. 41-48 (2003) 